\title{
Developing Learning Model of Life Skills-Based Courses in University
}

\author{
Djalal Fuadi ${ }^{1}$, Joko Suwandi ${ }^{2}$, Sutama $^{3}$, Maryadi ${ }^{4}$ \\ \{df276@ums.ac.id ${ }^{1}$,js171@ums.ac.id ${ }^{2}$, sut197@ums.ac.id ${ }^{3}$, mar243@ums.ac.id $\left.{ }^{4}\right\}$ \\ 1,2,3,4 Universitas Muhammadiyah Surakarta, Surakarta, Indonesia
}

\begin{abstract}
This study aims to arrange the course learning model with the life skills perspective in every learning process at Higher Education. Thus, graduates are expected to have qualified life skills value and benefit value in which learning model starts from syllabus, Lecture Quality Plans (called RMP) and learning model implementation applied in Teaching-Learning Stage for Genre-Based Approach.The method used was research and development. Data were collected through observation, in-depth interviews, document studies, and policy studies. Data validity was maintained by conducting the triangulation of sources, methods, investigators, and theories, while data analysis in sequential periods used SWOT analysis, interactive analysis, and implementation analysis. The results revealed that 1) The results of the field test and feasibility test of the syllabus in the Teacher Training and Education Faculty of Universitas Muhammadiyah Surakarta (called FKIP UMS) showed that all courses could include life skills in which not all life skills should be included in learning, then, at the level of learning process implementation and evaluation, it could focus not only on developing academic skill or vocational skill (hard skill) but also on aspect of developing life skill components which could be fully included. Implementation of Special Skill Learning Outcome (called CP-KK) of the courses could use various learning methods and assignment forms, and also life skill content could be developed in a complex manner. 2) The results of field tests and feasibility tests on RMP on the courses indicated that the use of learning methods including learning approaches, strategies, and techniques could use various approaches. Many approaches are based on academic competence, vocational competence, and also on cross-curriculum competency (social and personal competencies). 3) Implementation of stages could show the existence of stages specifically, sustainably, and consistently to simultaneously develop the four components of life skills (social, personal, vocational and academic competencies). The learning model can be implicitly mentioned in the syllabus and RMP.
\end{abstract}

Keywords: Learning, learning experience, life skills.

\section{Introduction}

Data from the Central Bureau of Statistics (called BPS in Indonesia) in August 2015 showed that undergraduate unemployment rates reached 6.40 percent from 7.56 million people. While the Statistics Official News No.41/05/th.XXII dated May 6, 2019, showed that the average Open Unemployment Rate (called TPT in Indonesia) from February 2016 to February 2019 has decreased respectively: February 2016 (5.50\%), February 2017 (5.33\%), February 2018 $(5.13 \%)$ and February $2019(5.01 \%)$. While the character of the working population according to the level of education is reported: University 12.61 million people (9.75\%), Diploma 3.65 million people (2.82\%), Vocational High School 14.63 million people (11.31\%), Senior High 
School 23.30 million people (17.86\%), Junior High School 22.97 million people $(17.75 \%)$ and Elementary School 52.40 million people $(40.51 \%)$. This means that there is a lack of graduates who cannot meet the demands of the workforce. Dwi mentioned there is a lack of life skills [1]. This is reinforced by the statement of the Minister of Manpower, M. Hanif Dhakiri, who considers the Higher Education only oriented to the mastery of science and technology. Then what is the significance of life skills for job seekers?

The National Association of Colleges and Employees in 2002 survey pinpointed that there are at least nineteen abilities needed in the world of work. The interesting thing about the survey is the achievement index as one of the manifestations of academic ability as the performance value of higher education institutions is in the 16th position. While the order of 1-7 is occupied by life skills, such as; communication, integrity, cooperation, interpersonal, work ethic, initiative, and adaptation. The government through Government Regulation Number 19 Year 2005 had responded to the importance of life skills for students. Article 13 stated that life skills education must be included in the curriculum including personal, social, academic and vocational skills. This means that higher education is not only mastering knowledge and technology but also developing certain skills, attitudes, and values that can be reflected in the graduates' lives. Viewed from the life facts nowadays, it is showed; 1) the occurrence of changes in life in society as a result of technological development and the social environment which has narrowed the opportunities for the development of social skills and personality and;2) the adjustment to life competition (both personal life and work life) requires mastery of hard skills and soft skills [2].

Some universities in implementing the message of article 13 are still half-measures. At the level of the preparation of the curriculum and syllabus, it most has included the development of hard skills and soft skills, but at the level of the implementation of the learning process, it is difficult to carry out well. In the learning process, it tends to emphasize knowledge aspects but emphasizes only a little aspect of skills, while, life skills are not included yet. This includes what happened at the Universitas Muhammadiyah Surakarta in Teacher Training and Education Faculty (called FKIP UMS). The results of the team's review of the curriculum and syllabus show that all courses have actually contained life skills, but at the level of the implementation of the learning process and evaluation, it is still focused on developing academic or hard skills which have not included aspects of life skills development yet. Based on the description above, the problem of this research was focused on "How to develop courses learning model based on life skills?" The focus of this research is then detailed in three stages. The first stage was focused on identifying and analyzing syllabus and Lecture Quality Plans (called RMP) and analyzing the implementation of life skills-based learning at the FKIP UMS. The second stage was developing the draft model (develop a preliminary form of the model) and the third stage was drafting the syllabus, RMP and life skills-based learning courses that are implemented in the Teaching-Learning Stage for Genre-Based Approach. At the end of this study, it compiled the course learning model based on life skills implemented in the Teaching-Learning Stage for Genre-Based Approach which for the further stage was disseminated and implemented in learning.

The innovation targeted in this study is to contribute to the development of course learning models that support the goal of national education to form a plenary human being through education oriented to life skills-based learning. The application of life skills-based learning models from the results of the study is very beneficial for education at the Teacher Training and Education Faculty in creating plenary graduates.

The World Health Organization (WHO) defined life skills as "the abilities for adaptive and positive behavior that enable individuals to deal effectively with the demand and challenges of 
everyday life". A life skill is the ability of one to behave positively and adaptively that can be used effectively to deal with the demands and challenges of survival. UNICEF emphasized that "life skills is a behavior change or attitude development approach designed to address a balance of three areas: knowledge, attitude, and skills". A life skill is considered as an approach to change or behavior development aimed at forming someone to have a balance between knowledge mastery, attitude, and skill.

Related to life skills perspective learning, it is an effort to empower human beings with all the competencies they have to carry out positive activities to improve a better quality of life [3]. Life skills will have broad meaning if the learning activities designed to provide a positive impact on university students to help to solve life problems as well as to overcome the life problems proactively and reactively to find the right solution [4][5]. To achieve these things, it needs to implement broad-based educational principle that is not merely oriented to the academic or vocational field, but also provides learning how to learn as well as learning how to compare and not only learning theory but also practicing to solve everyday life problems (Bentley in Asmani [3]).

This study develops a life skills perspective model from Bentley which will be implemented in learning university courses related to the scientific basis of the art of teaching. In detail, it is described in the form of schematics as follows:

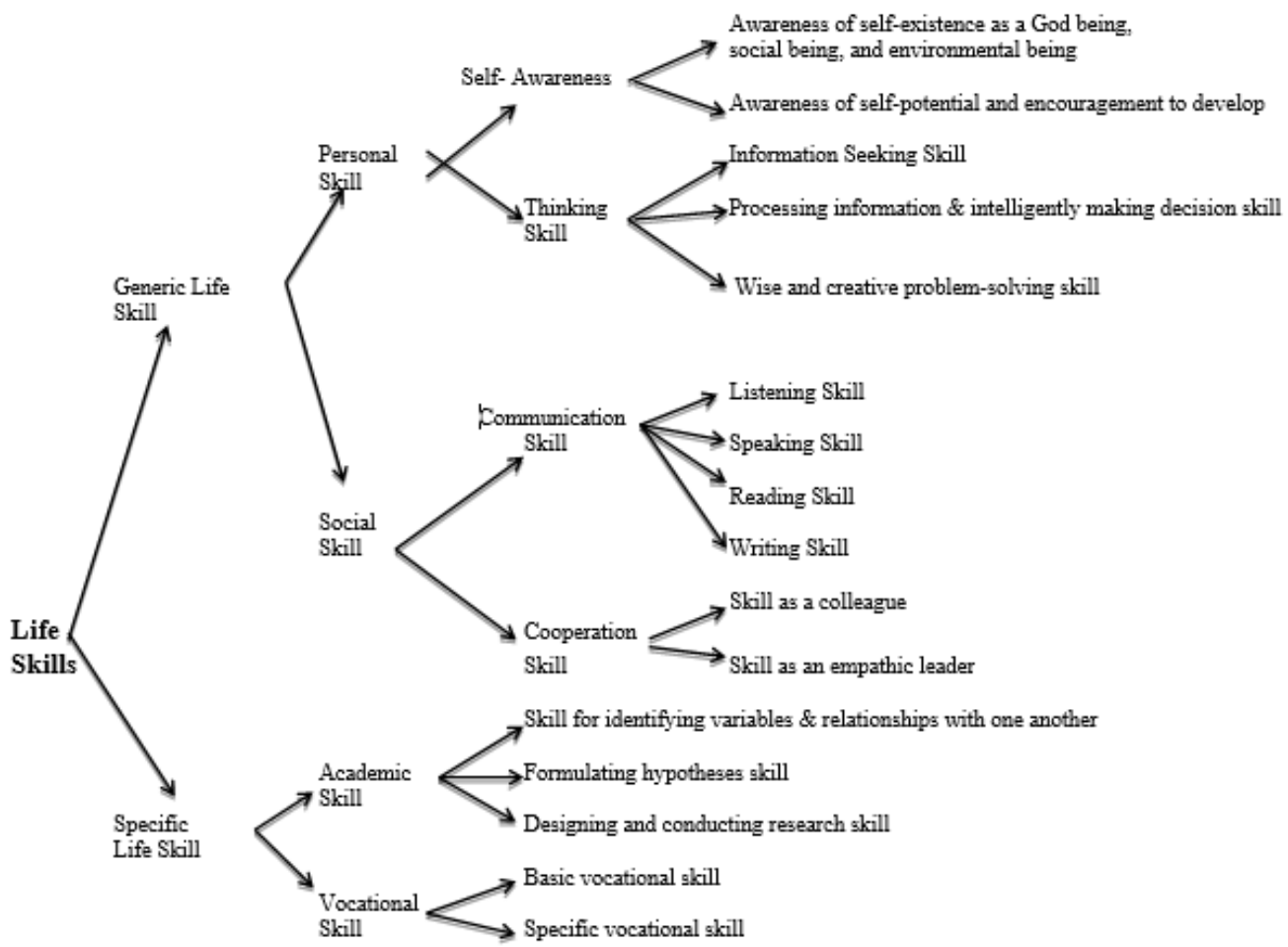

Teaching-Learning Stages for A Genre-Based Approach is a learning approach based on various steps in which this approach is widely used for skills formation so it is very appropriate to be adopted for learning that will help students mastering life skills because it emphasizes more on mastery of skills and application in socio-cultural [6]. 
This approach is more based on the achievement of competencies, namely academic competence, vocational competency and cross-curriculum competency which are categorized social and personal competencies. Four stages are carried out to provide opportunities for students to gain learning experiences through individual, paired and group activities, including Building knowledge of field in which students are gradually invited to build an understanding of what is learned and the things associated with it. Modelling, it means students will understand something easily if introduced to things that already exist or are similar to models to build their understanding of something. Joint construction, in this stage, it is to accelerate mastery of what is learned in which students are involved in various activities in a large or small group, and/ or in pairs, to gain experience from others. The last stage is Independent construction. It is to strengthen understanding and skills through individual learning experiences.

The learning model that can be used is an active learning model that emphasizes studentoriented, and is multi-model for each stage, according to the character of the courses and expected competencies. Learning models include; problem based learning, cooperative learning, collaborative learning, project based learning, contextual instruction, small group discussions, simulation, discovery learning, and directed learning. Thus, in a gradual, sustainable, and consistent manner can simultaneously develop four components of life skills consisting of social, personal, vocational and academic competencies.

As viewed from a message by the Republic of Indonesia Law No. 20 Year 2003 that education is a conscious and planned effort to realize a learning atmosphere and learning process so that students actively develop their potential to have religious-spiritual powers, self-control, personality, intelligence, noble character and skills needed by themselves, society, nation, and state. It is appropriate for the learning process to be more oriented to life skills-based learning in which it is no longer based on a supply-driven approach. In the supply-driven approach, what is taught tends to emphasize on school-based learning which is not necessarily fully suitable with the real-life values faced by students. A suitable approach is a demand-driven approach in which what is taught is a reflection of real-life values faced by students and will be taught through the Teaching-Learning Stage for Genre-Based Approach.

\section{Method}

The type of research used was Research and Development means the research process used to develop and validate research products [7]. The steps of this model include ten activities, include; 1) Preliminary study, 2) Research planning, 3) Initial product development, 4) Initial field trial (limited), 5) Revision of the results of limited field test, 6) Broader field test, 7) Revision of field test results, 8) Feasibility test, 9) Revision of the results of the feasibility test, and 10) Dissemination and socialization of the final product.

\section{Result and Discussion}

\section{Syllabus of life skills-based courses in FKIP UMS}

The results of the field tests and feasibility tests of the curriculum and syllabus of the courses in FKMS UMS showed that all courses could contain life skills. At the level of implementation, the learning process and its evaluation as contained in the syllabus were not only focused on developing academic or hard skills but also could fully incorporate aspects of life skills 
development. In implementing the Special Skills Learning Outcomes (called CP-KK), each course could use various learning methods and assignments in which the life skills content is quite complex to be included in the courses as examples of courses contained in the syllabus in the following table:

Table 1. Syllabus of five courses of FKIP UMS Process

\begin{tabular}{|c|c|}
\hline Course & life skills Content \\
\hline $\begin{array}{l}\text { Philosophy of } \\
\text { Education } \\
103402 / 2 \\
\text { / } 2 \text { credits }\end{array}$ & $\begin{array}{l}\text { Awareness of self-existence as a God being, social being, and environment } \\
\text { being (KD) } \\
\text { Awareness of self-potential and encouragement to develop (KD) } \\
\text { Information seeking skill (KBr) } \\
\text { Processing information \& making decision skill (KBr) } \\
\text { Wise and creative problem-solving skill (KBr) } \\
\text { Listening skills (KK) } \\
\text { Speaking skills (KK) } \\
\text { Reading skills (KK) } \\
\text { Writing skills (KK) } \\
\text { Skill as a colleague (KBk) } \\
\text { Skill as an empathetic leader (KBr) }\end{array}$ \\
\hline $\begin{array}{l}\text { Management of } \\
\text { Education } \\
302302 / 2 / 2 \\
\text { credits }\end{array}$ & $\begin{array}{l}\text { Awareness of self-existence as a God being, social being, and } \\
\text { environmental being (KD) } \\
\text { Awareness of self-potential and encouragement to develop (KD) } \\
\text { Personal skills (KP) } \\
\text { Information seeking skill (KBr) } \\
\text { Processing information \& intelligently making decision skill (KBr) } \\
\text { Wise and creative problem-solving skill (KBr) } \\
\text { Listening skill (KK) } \\
\text { Speaking skill (KK) } \\
\text { Reading skill (KK) } \\
\text { Writing skill (KK) } \\
\text { Skill as a colleague (KBk) } \\
\text { Skill as an empathetic leader (KBk) } \\
\text { Skill for identifying variables \& relationships with one another (KA) } \\
\text { Formulating hypotheses skill (KA) } \\
\text { Designing \& carrying out research skill (KA) } \\
\text { Basic vocational skill (KV) } \\
\text { Special vocational skill (KV) }\end{array}$ \\
\hline $\begin{array}{l}\text { Curriculum and } \\
\text { Learning } \\
302303 / 2 \text { credits }\end{array}$ & $\begin{array}{l}\text { Special vocational skill (KV) } \\
\text { Awareness of self-existence as a God being, social being and environmental } \\
\text { being (KD) } \\
\text { Awareness of self-potential and encouragement to develop (KD) } \\
\text { Information seeking skill (KBr) } \\
\text { Processing information \& intelligently making decision skill (KBr) } \\
\text { Wise and creative problem-solving skill (KBr) } \\
\text { Listening skill (KK) }\end{array}$ \\
\hline
\end{tabular}




\begin{tabular}{|c|c|}
\hline Course & life skills Content \\
\hline & $\begin{array}{l}\text { Speaking skill (KK) } \\
\text { Reading skill }(\mathrm{KK}) \\
\text { Writing skill }(\mathrm{KK}) \\
\text { Skill as a colleague (KBk) } \\
\text { Skill as an empathetic leader (KBk) } \\
\text { Skill for identifying variables \& relationships with one another (KA) } \\
\text { Formulating hypotheses skill (KK) } \\
\text { Designing \& carrying out research skill (KA) } \\
\text { Basic vocational skill }(\mathrm{KV})\end{array}$ \\
\hline $\begin{array}{l}\text { Guidance and } \\
\text { Counseling } \\
303307 / 2 \text { credits }\end{array}$ & $\begin{array}{l}\text { Awareness of self-existence as a God being, social being and environmental } \\
\text { being (KD) } \\
\text { Awareness of self-potential and encouragement to develop (KD) } \\
\text { Information seeking skill (KBr) } \\
\text { Processing information \& intelligently making decision skill (KBr) } \\
\text { Wise and creative problem-solving skill (KBr) } \\
\text { Listening skill (KK) } \\
\text { Speaking skill (KK) } \\
\text { Reading skill (KK) } \\
\text { Writing skill (KK) } \\
\text { Skill as a colleague (KBk) } \\
\text { Skill as an empathetic leader (KBk) } \\
\text { Skill for identifying variables \& relationships with one another (KA) } \\
\text { Formulating hypotheses skill (KA) } \\
\text { Designing \& carrying out research skill (KA) } \\
\text { Basic vocational skill (KV) } \\
\text { Special vocational skill (KV) }\end{array}$ \\
\hline $\begin{array}{l}\text { Educational } \\
\text { Psychology } \\
\text { 303308/2 credits }\end{array}$ & $\begin{array}{l}\text { Speaking skill (KK) } \\
\text { Reading skill (KK) } \\
\text { Writing skill (KK) } \\
\text { Skill as a colleague (KBk) } \\
\text { Skill as an empathetic leader (KBk) } \\
\text { Skill for identifying variables \& relationships with one another (KA) } \\
\text { Formulating hypotheses skill (KA) } \\
\text { Designing \& carrying out research skill (KA) } \\
\text { Basic vocational skill (KV) } \\
\text { Special vocational skill (KV) } \\
\text { Awareness of self-existence as a God being, social being and environmental } \\
\text { being (KD) } \\
\text { Awareness of self-potential and encouragement to develop (KD) } \\
\text { Information seeking skill (KBr) } \\
\text { Processing information \& intelligently making decision skill (KBr) } \\
\text { Wise and creative problem-solving skill (KBr) } \\
\text { Listening skill (KK) }\end{array}$ \\
\hline
\end{tabular}


Notes:

KD : Self-Awareness (Personal Skill/ Generic Life Skill)

$\mathrm{KBr}$ : Thinking Skill (Personal Skill/ Generic Life Skill)

KK : Communication Skill (Social Skill/Generic Life Skill)

KBk : Cooperation Skill (Social Skill/Generic Life Skill)

KA : Academic Skill (Specific Life Skill)

KV : Vocational Skill (Specific Life Skill)

\section{Lecture Quality Plan (RMP) of Life Skills-Based Courses}

The results of the field test and feasibility test on RMP in the course showed that the use of learning methods in the form learning approaches, strategies and techniques could use a varied approach. A more competency-based approach means to achieve academic, vocational and cross-curriculum competencies that are social and personal. The stages to provide opportunities for students to obtain learning experience could be done through individual activities (often), in pairs (rarely), in groups (sometimes) through four stages including: First stage, through the Building knowledge of fields in which students are gradually invited to build an understanding of what is learned and the things associated with it. This stage is done to explore and introduce topics/media/cases/literacy to be discussed. If the text/media/case/literacy to be taught is a procedure, then the lecturer and students are involved in conversations related to the text/media/case/literacy. Learning activities developed include: 1) Brainstorming. It is to develop students' readiness and understanding of texts/media/cases/literacy to be conveyed, 2) developing students' understanding of vocabulary/ relevance between cases in the media/relevant problematic/relevant literacy development, 3) visual sequencing (students compile images in visual media), 4) discussion of visuals related to context (studying the relevance of visual images to context), 5) discussion of experiences in indigenous culture (study of relevant experience in local culture), 6) discussion about experience in the target culture (relevant experienc study in language culture), 7) exercise of general text identification (practicing recognizing text/ media/ problem/ general literacy with the type of text/ media/ problem/ literacy to be discussed), 8) exercise of text/ media/ problem/ literacy categorization (categorization of text/ media/ problem/ literacy extracted), 9) predicting activities ( the practice of text/ media/ problem / subsequent guess literacy) and 10) suitable activities (practice making match pictures with words, words with synonyms, etc.), and 11) introductory activities (the practice of introducing text/media/ problema/ literacy writing formats).

In the second stage, through Modelling, students are introduced to things that already exist or are similar to models to build their understanding of something. Modelling is oriented to concentration, increased motivation, delivery of competencies, direction, instructions, signs, and examples. Students are easier to understand something if introduced to things that already exist or are similar to models to build their understanding. This stage is the stage of exposure to the material being taught. At this stage, the skills being trained are analyzing types of text/ media/ problematic/ literacy, reading and writing. 
Life skills-based learning activities developed in the Modelling stage include: 1) The lecturer shows the model through exposure to text/ media/ problem/ literacy and mentions it in other forms/ synonyms/ models/ categories, then prepares it in front by explaining; 2) After hearing directly from the lecturer, the work role then switches from lecturer to student. Students get the opportunity to demonstrate and practice their abilities. There are two choices that the lecturer can give to students. The first choice is students are asked to repeat the whole procedure/ object/ material that has been explained, and the second choice is students are asked to answer questions related to the procedure/ object/ material that has been explained. 3) When the class goes on the writing cycle stage, students are introduced to the language of writing the text through the reading method (exposure information by reading). Students are given examples of procedures/ objects/ material and the lecturer explains particular things to them, especially the generic structure of the text/ media/ problem/ literacy. 4) When the class is in the oral cycle (listening and speaking), the lecturer provides modeling to students. For instance, how to make a title, how to arrange an organizational structure, etc. 5) Demonstrate visually, auditorily and kinesthetically how to make something by practicing it directly. 6) Students get the opportunity to demonstrate and practice their abilities to demonstrate based on the modeling.

Third, Joint construction means to accelerate mastery of what is learned in which students get the opportunity to carry out various activities in groups both large, small and/ or in pairs. this is done to obtain experience from others. Life skills-based learning activities that are developed in the Joint construction phase, include:

a) To stimulate student curiosity, activities that can be carried out include:(1) Asking complex questions/ problems that have several possible answers. This is intended to stimulate student curiosity about the material to be taught. The questions can be daily questions such as how to do things, definitions, ways of working (procedures). (2) Encouraging students to think, make schemes or diagrams, and make a general assumption. (3) Accommodating all student assumptions. It means creating curiosity about the real answer. As a variation, ask students to pair up and make predictions collectively.

b) To stimulate students to learn independently by: (1) Delivering the text/ object/ material model to students, accompanied by several questions/ problems in sequence from simple to complex. (2) Providing opportunities for students to study the text/ object/ material model independently. (3) Asking students to mark material that they do not understand and arrange questions in writing as much as the material marked. (4) Providing opportunities for other students to respond to the questions until all student's questions have been discussed, (5) Providing explanations as a means of stabilization of answers to student's questions. (6) Asking students to solve problems independently, (7) Asking students to present answers to the problems given and allowing other students the opportunity to comment or suggest other possible answers. (8) Providing clarification or stabilization of answers to questions. If students face difficulties, the lecturer needs to provide some information that guides them.

c) To stimulate students to study in pairs, through activities: (1) Providing opportunities for students to choose partners, (2) Giving different problems to each partner to solve, (3) Asking each pair to exchange answers and make new answers for each problem, and also correct each partner's answer, (4) Asking each pair to return the answer to the owner if all partners have written new answers, (5) Providing opportunities for the pairs to compare the answers of each pair with the answers from other pairs in the class. (6) Asking all students to choose the right answer for each question and present the best answer. (7) Giving reward a student who has the best answer. 
d) To stimulate students to learn together in the group through activities such as (1) Providing opportunities for students to study text in a small group or large group, (2) Asking students to write down unknown things in the form of questions. (3) Providing opportunities for discussion groups to discuss questions from each group member. (4) Giving the task of problem-solving to each group, with clear instructions. (5) Giving roles to group members to work in groups, for example as a facilitator, note-taker, spoke person, and timer. (6) Providing opportunities for each group to solve problems and present the results of discussions in front of the class.

e) To stimulate students to learn in the form of learning tournaments, using (1) Divide students into some groups of two to eight students. Make sure that the group has the same number of members. Ask each group to name the group. (2) Provide teaching materials to the group to learn together. (3) Make several questions that can test the level of understanding of the material provided. Use a format that facilitates self-assessment, (4) Ask students in each group to answer individually. (5) Ask group members to check the answers of friends on the team. (6) Conduct class discussions to determine the correct answer to the question. (7) Ask students to count the number of questions they answer correctly and ask them to give a score. (8) Ask students to combine their scores with their team members to have a group score. (9) Announce the score of each group and give rewards or prizes or applause to the group that gets the highest score.

This tournament can be done with the number of rounds varying and the time of each round can be varied but make sure that each round of students carries out a study session. With student agreement, the lecturer can give penalties (punishments) to students who provide wrong answers with a reduction in value (eg. -1 or -2 ) and give value to students who do not answer.

In the fourth stage of Independent construction, the students get the opportunity to strengthen their understanding and skills through individual learning experiences. Life skills-based learning activities developed in the Independent/ Individual Construction stage are students start to apply their learning knowledge and experience independently. This activity is the highest stage in mastering the material which means as the ability to independently produce an oral or written monologue text. If it is deemed necessary, the lecturer can add activities to make text conversations independently under the theme being taught. At this stage, text sharing is expected to occur by displaying text and discussing it in the lecture. This activity as part of building a positive attitude, to mutual respect for the peers' performance. The stages of this activity are carried out through (1) forming groups with some texts learned by students, (2) providing opportunities for each group to obtain much information, concepts, or skills to be conveyed to other students. (3) providing the opportunity for each group to arrange ways to present or teach the texts to other students. (4) giving students the opportunity to summarize or make an overview of the lecture that day, (5) motivating students to review lecture material and or complete assignments independently or in groups, (6) giving each group the opportunity to present their lecture, and give appreciation for their efforts, (7) as an alternative to learning this model is to ask students to teach or provide guidance to other students individually or in small groups. 
The learning model used in the course is an active learning model that emphasizes studentoriented, and is multi-model for each stage, according to the character of the courses and expected competencies. The implementation of the stages can show the existence of stages specifically, sustainably, and consistently to develop simultaneously the four components of life skills (social, personal, vocational and academic competencies). Learning models can be specifically or implicitly mentioned in the learning model, for example; problem based learning, cooperative learning, collaborative learning, project based learning, contextual instruction, small group discussion, simulation, discovery learning, or directed learning.

The results of field test and RMP feasibility test of several life skills-based courses can be stated that each course in carrying out Learning Outcomes in Lecture is conducted through indicators, while, delivering teaching material is done using different learning methods in the form of approach, strategy, and technique. Based on the analysis results of the RMP course, it can be stated that the Learning Method (approach, strategy, technique) chosen by most courses include:

(1) Constructivistic, (2) individual model of Cooperative Learning, (3) reviewing concepts and discussing problems, (4) reviewing and discussing various elements and functions based on expert opinion, (5) reviewing components, (6) reviewing and discussing concepts and application, (7) conducting observations, (8) explaining and reviewing the material, (9) questionning and answering, (10) group discussions, (11) demonstrations, (12) group and individual assignments, (13) lectures, (14) class discussion, (15) paper presentations, (16) methods: Active learning, Strategy: reading guiding strategy, (17) Methods: discussion, Approach: Active learning, strategy: Problem Based Introduction, (18) method: discussion, Approach: Active learning, strategy: Snowball Throwing, (19) method: discussion, Approach: Active learning, strategy: earning starts with a question, (20) method: discussion, Approach: Active learning, strategy: reading guiding strategy; (21) method: discussion, approach: Active learning, strategy: everyone is here teacher strategy, (22) method: assignment, approach: Active learning, strategy: everyone is a teacher here strategy; (23) method: discussion, Approach: Active learning, strategy: role playing, (24) method: discussion, Approach: Active learning, strategy: jigsaw, and (25) method: discussion, approach: Active learning, strategy: Student Teams Achievement Devision (STAD).

The learning approach used by each university course is based on various steps and is oriented to the formation of skills so that most courses have led to learning that will help students master life skills because they emphasize mastery of skills and application in socio-cultural. 


\section{Learning implementation of life skills-based courses}

The implementation of the learning of education model based on life skills perspective that is implemented in subjects related to the scientific basis of the art of teaching can be reported as follows, (1) The learning model can fully use active learning model that emphasizes on Student Oriented, and in the learning process can be multi-modeled for the learning stage, so, the direction of learning objectives leads to the expected character of the lesson topic and competency. In developing life skills-based learning, almost all courses can be implemented with life skills-based learning especially those related to Specific Life Skills, including academic skill and vocational skill. Furthermore, it can develop a life skills perspective model that has broader educational principles which are not only oriented to academic skills (identifying variables and relationships, formulating hypotheses and designing and carrying out research skills) or vocational skills (basic and specific vocational skills) only. (2) Learning in each subject can fully lead to four components of life skills which include: a) Personal skill, in which some courses routinely carry out learning that leads to Self-Awareness that includes awareness of self-existence of as a God being, social being and environmental being; and awareness of self-potential and encouragement to develop. Learning implementation in each opening activity of the lecture begins with reading prayers and short sura in the Quran led by one of the students based on a schedule prepared by them. For students who are not fluent in reading, there will be self-awareness and encouragement to develop themselves to read the Quran. For Thinking Skills consisting of information-seeking skill; processing information \& inteligently making decision skill; and wise and creative problem-solving skill, almost all courses use this approach as a means to develop student life skill in which the methods used are very varied including (1) constructivistic, (2) cooperative learning individual model, (3) reviewing concepts, discussing problems, discussing various elements and functions based on expert opinion, (4) reviewing components, concepts and applications, (5) observing, (6) explaining and reviewing material, (7) question and answer, (8) group discussions, (9) demonstrations, (10) group and individual assignments, (11) lectures, (12) class discussions, (13) paper presentations, (14) method: Active learning, Strategy: reading guiding strategy, (15) Method: discussion, Approach: Active learning, strategy: Problem Based Introduction, (16) method: discussion, Approach: Active learning, strategy: Snowball Throwing, (17) method: discussion, Approach: Active learning, strategy: learning starts with a question, (18) method: discussion, approach: Active learning, strategy: everyone is here teacher strategy (19) method: assignment, approach: Active learning, strategy: everyone is a teacher here; (20) methods: discussion, approach: Active learning, strategy: role playing, (21) method: discussion, Approach: Active learning, strategy: jigsaw, and (22) method: discussion, approach: Active learning, strategy: Student Teams Achievement Devision (STAD). b) Social Skill, this skill includes communication skills (listening skill, speaking skill, reading skill and writing skill); and cooperation skills (skill as colleagues and skill as an empathetic leader). Implementation for Social Skill each course can use a method such as a group discussion, assignment presentation and report (powerpoint and written), preparation of the paper, group/ independent/ paired assignment, questioning. c) Academic Skills include the skill to identify variables \& relationships with one another, skill to form hypotheses; and skill to design \& carry out research. Almost all courses incorporated in educational courses have not implemented these skills yet in the learning process because these skills are closely related to research methodology where this course is included or conducted in the third or fourth semester, while, the Education courses are held in semester one or two. d) Vocational skill, this skill is divided into two skills including basic vocational skill and specific vocational skill. 


\section{Conclusion}

The results of field test and RMP feasibility test and course syllabus indicate that all courses can be included in the scope of life skills in which at the level of learning process implementation and evaluation can be focused on developing academic or vocational skill (hard skill), and can fully incorporate aspects of life skill development. In implementing Special Skills Learning Outcomes (called CP-KK), each course can use various learning methods and assignments that have sufficient soft skills.

The results of the field test and RMP feasibility test in several courses show that the use of learning methods in the form of learning approaches, strategies, and techniques used a varied approach. A competency-based approach means to achieve academic, vocational and crosscurriculum competencies that are social and personal competency. Stages to provide opportunities for students to obtain learning experience through individual, in pairs or group activities are through four stages which include: the first stage is through the Building knowledge of the field. It means students are gradually invited to build an understanding of what is learned and things associated with it. In the second stage, through Modelling, students are introduced to things that already exist or are similar to models to build their understanding of something. Third, Joint construction is to accelerate mastery of what is learned in which students are provided the opportunity to carry out several activities in large or small groups and/ or in pairs. This is done to obtain experience from others. While the fourth stage, namely Independent construction, means students get the opportunity to strengthen their understanding and skills through individual learning experiences.

The learning model can fully use active learning model that emphasizes Student Oriented, and in the learning process, it can be multi-model for the learning stage so that the direction of learning objectives can lead to the expected character of lesson topic and competency in developing life skills-based learning almost all courses can be implemented through life skillsbased learning especially those related to Specific Life Skills including academic skill and vocational skill. All things considered, it needs to develop a life skill perspective model and has the broader educational principle that is not only oriented to academic skill (identifying variables and relationships skill, formulating hypotheses skill and designing and carrying out research skill) or vocational skill (basic and specific vocational skill).

The implementation of the stages has shown that there are stages that are specific, sustainable, and consistent to simultaneously develop four components of life skills (social, personal, vocational and academic competencies). Learning model specifically or implicitly can be mentioned in the learning model, as an illustration; problem based learning, cooperative learning, collaborative learning, project based learning, contextual instruction, small group discussion, simulation, discovery learning, or directed learning. Learning in each course can lead to four components of life skill including Personal Skill, Social Skill, Academic Skill, and Vocational Skill.

\section{Acknowledgament}

We are thanking everyone supporting our research. We thank to Research and Society Submission, Directorate General of Research Enforcement and State Minister for Research and 
Technology, and Directorate General of Higher Education which have supported us in funding this multi-year research through Graduate Team Research Grant. We also thank to Dean of Teacher Training and Education and The Chief of Research Institution UMS and staff, for providing facilities and encouragement so that we can accomplish this research. We also thank to the Head of State Minister for Youth and Sport.

\section{References}

[1] T. F. Dwi, "Lulusan Sarjana S1 Mengaggur Karena 5 Alasan,” 2016. [Online]. Available: https://www.linkedin.com/pulse/400000-lulusan-sarjana-s1-menganggurkarena-5-alasan-tommy. [Accessed: 19-Mar-2019].

[2] N. Ramadhani, "Active Learning and Soft Skills," in Seminar Nasional Memanfaatkan Soft Skills untuk Pembelajaran, 2008.

[3] J. M. Asmani, Sekolah Life Skills (Lulus Siap Kerja). Yogyakarta: Diva Press, 2009.

[4] S. Marwiyah, "Konsep Pendidikan Berbasis Kecakapan Hidup.," J. FALASIFA, vol. 13, no. 1, pp. 75-97, 2012.

[5] N. Ishartono and S. Sufahani, "A Metacognition Analysis of Male and Female PreService Teachers in Making PowerPoint ( PPT ) as a Learning Media," no. 1, pp. 1184-1190, 2019.

[6] P. Hendricks, "Developing Youth Curriculum Using the Targeting Life Skills Model," 2010. [Online]. Available: http:/www.extention.iastate.edu/4h/explore/lifeskills.diakses. [Accessed: 16-Mar2019].

[7] W. R. Borg and J. P. Gall, Educational Research: an introduction. New York: Longman Inc, 1979. 